\title{
HUMAN RIGHTS IN THE PEACE TREATIES*
}

\section{StePHEN D. KerTesZ $\dagger$}

"The Charter recognizes that social progress and higher standards of life grow from larger freedom. Man does not live by bread alone. The Universal Declaration of Human Rights, one of the greatest achievements of the third session of this Assembly, constitutes a long stride forward in our efforts to free men from tyranny or arbitrary constraint. The United States attaches great importance to this work of the United Nations.

"This year we are confronted with a concrete issue in this field, the question of observance of human rights in Bulgaria, Hungary and Rumania. The treaties of peace with these countries set forth the procedures for the settlement of disputes arising under these treaties. Within the last few weeks Bulgaria, Hungary and Rumania have refused to follow these procedures.

"This issue involves more than the violation of terms in a treaty. It affects the rights and freedoms of all the people who live in these three states."

$$
\begin{aligned}
& \text { Address by Secretary Acheson to the United } \\
& \text { Nations General Assembly on September } \\
& 2 \pi, \text { rg49. }
\end{aligned}
$$

The five Peace Treaties, signed on February 10, 1947, with their declarations of principle and concrete provisions for the protection of human rights and fundamental freedoms not only are the production of a long evolution but also are an integral part of a world wide aspiration for the protection of human rights. This program has received its most sweeping and inspiring formulation in the obligations assumed by member states in the United Nations Charter.

- The following abbreviations are used in the footnotes:

(1) Dep't State Bull.-Bull.

(2) Paris Pence Conference i946 Selected Documents (U. S. Dep't State, r946)-Selected DOCUMENTS.

(3) Treaties of Peace with Italy, Rumania, Bulgaria, and Hungary, Hearings before the Senate Committee on Foreign Relations, 8oth Cong., Ist Sess. (1947)-Hearings.

(4) The Peace Treaties will be quoted in the following form: Peace Treaty with Bulgaria-B.T., Peace Treaty with Finland-F.T., Peace Treaty with Hungary-H.T., Peace Treaty with Italy, I.T., Peace Treaty with Rumania-R.T.

†LL.D. 1926, Univ. Peter Pazmany of Budapest. Diploma of Institut des Hautes Etudes Internationales de l'Université de Paris, 1928. Lecturer, Faculty of Law, Univ. Peter Pazmany of Budapest. Visiting Lecturer in Yale Law School since I948. Rockefeller fellow in the United States, Great Britain, and Switzerland, I935-1937. Ass't. to Agent of Hungarian Government in cases before Permanent Court of International Justice at The Hague, 1932-1934. Various positions with Hungarian Government, 19381944. Imprisoned and court-martialed by the Hungarian Nazi Regime, I944- Head of the section of the Hungarian Foreign Ministry charged with the preparatory work for the Peace Conference, 1945. Secretary General of the Hungarian peace delegation, 1946. Chief of the Division for International Relations in the Hungarian Ministry for Foreign Affairs, I946. Hungarian Minister to Italy, 1947. Resigned from the Hungarian foreign service, 1947. Author, INTERNationar Responsibility of THE State (1938). Contributor to various Hungarian, French, and English legal and political periodicals.

IN. Y. Times, Sept. 22, 1949, p. 6, col. 1 . 
The principle enshrined in the long historical development and in these new agreements was fundamental in classical Roman Law: "hominem causa constitutum omne ius." In modern times the welfare of the individual is the raison d'ettre and the final aim of all well conceived democratic systems of law. The protection of human rights in international law is not an entirely new phenomenon. The importance of the Peace Treaties as of the United Nations Charter is in their direct and deliberate use of agreement to supplement the indirect and mostly ineffective concern of traditional customary international law for protecting the human being against the abuses of his own state. Americans may well be proud that the new landmarks embodied in the Peace Treaties are a result of the suggestion of their statesmen.

The human rights provisions, inserted into the recent Peace Treaties, are in harmony with, and represent a logical outcome of, a long development in international law and practice. This evolution began with the protection afforded to religious groups in the era following the Reformation. The principle "cuius regio eius religio," inserted into the peace treaties terminating the great religious wars, ${ }^{1}$ recorded progress of a kind after a period of general chaos and intolerance. This principle, however, did not protect the religious freedom of individuals. It left the door wide open for bigotry and persecutions, since it gave freedom to choose religion only to the rulers. The individuals were obligated to accept the official religion of the state or to emigrate. The Treaty of Vienna, concluded between the Emperor Rudolph II and Stephen Bocskay, the Protestant Prince of Transylvania, in 1606 , offers an early example of religious freedom guaranteed for individuals in a Peace Treaty. ${ }^{2}$

The great body of international instruments guaranteeing religious freedom for individuals is of more recent origin and is mostly connnected with changes of sovereignty and recognition of new states. This became the general practice in the nineteenth century, especially in the course of dismemberment of the "sick man of Europe." The recognition of the new Balkan states, formerly belonging to the Ottoman Empire, was made conditional upon their acceptance of religious freedom. At the same time the Sultan was repeatedly pressed to make "spontaneous" declarations concerning religious tolerance. ${ }^{3}$ For instance, following the Crimean war, the Sultan declared solemnly in a Firman that all his people were equally dear to him. By the same Firman all the existing privileges were confirmed, full religious liberty was guaranteed, and every Turk citizen, without regard to his faith, could hold official positions. These solemn declarations, however, did not prevent the periodically recurring persecutions and massacres of the Christian population in the Ottoman Empire, which caused general indignation in the western world.

\footnotetext{
${ }^{1}$ For example, in the treaty of Augsburg (1555), and in the Treaties of Osnabruck and Munster (1648) terminating the Thirty Years War.

25 Jean Dumont, Corps Universed Diplomatique du Droit des Gens, Pt. 2, 69-73 (1728).

${ }^{8}$ Cf. Art. IX of the Treaty of Paris, signed March 30,1856 in Paris. I5 Georg F. Martens, Nouvenu RECUEIL DE TrAitís 774-775 (1857). In the same sense Art. LXII of the Treaty of Berlin, signed July 13, I878. 3 Georg F. Martens, Nouvenu Recueil de Traitks 464 (2d ser. 1878.)
} 
The protection of religious freedom, inserted into peace treaties and other international instruments, served sometimes as a pretext for political interventions. This was an especially favored tool of the Great Powers in their struggle in the Balkans. As early as I774, in Article VII of the treaty of Kuchuk-Kainarji, ${ }^{4}$ the Sultan recognized Russia as the protector of the Greek Orthodox population in his realm. The Roman Catholics were protected in the Middle East by France, in the Balkans by Austria. A quarrel between France and Russia over the religious buildings and holy relics in the Holy Land was one of the pretexts for the outbreak of the Crimean war.

In most of the cases the protection afforded in the sphere of religion implied protection of specific national minorities. There are a few instances in the nineteenth century when national minorities as such were given international guarantee. For example, Article I, Section 2 of the final Act of the Congress of Vienna, signed on June 9, I8I5, guaranteed to Poles living under Austrian, Prussian, and Russian sovereignty the maintenance of their national institutions and a national representation. This provision was used by Britain, France, and Austria at the occasion of their interventions, when Russia crushed the two Polish revolutions of I830-3I and I863-64.

Besides protection given to religious and national minorities, peace treaties in certain areas of the world guaranteed special rights and protection to foreigners. In the Middle East and Far East the development of the systems of the capitulations and concessions is the best illustration of this particular kind of protection. ${ }^{6}$

The treaty of Paris in 1856 , followed by that of Berlin in 1878 , introduced the system of the collective guarantee of the Great Powers. ${ }^{7}$ It was thought that a collective system was more likely to eliminate the abuses of arbitrary interventions of certain Powers for selfish political purposes. The practical results, however, did not mean a step forward on the path of progress. There was no machinery and established procedure to deal with the violations. Thus the value of the collective guarantee remained more theoretical than real.

\footnotetext{
2 Martens, op. cit. supra, note 3 , at 297 (1817).

"Les Polonois, sujets respectifs de la Russie, de l'Autriche et de la Prusses, obtiendront une représentation et des institutions nationales, réglées d'après le mode d'existence politique que chacun des Gouvernements, auxquels ils apartiennent jugera utile et convenable de leur accorder." 2 Martens, op. cit. supra note 3 , at 384 (1818).

The reserve included in the second part of this article is similar to some of the Soviet proposals put forward recently concerning the Covenant on Human Rights. For example, with respect to freedom of movement and residence, and freedom to leave a country, Mr. Pavlov proposed that these freedoms be subject to the laws of the country. He proposed that the freedom of religion article read: "Every person shall have the right to freedom of thought and freedom to practice religious observances in accordance with the laws of the country and the dictates of public morality." 21 BuLl. 9 (I949).

- The first capitulation was concluded between France and the Ottoman Empire in 1535 . By the Peace Treaty of Lausanne of July 24, 1923, the capitulations in Turkey were abolished. The Second World War swept away in China the remainders of the system of foreign concessions.

${ }^{7}$ Arts. XXII and XXVII of the Treaty of Paris, signed March 30, 1856, and the Treaty of Guarantee, signed April 15, 1856, in Paris. Georg F. Martens, 5 Nouvenu Recueil de Traites 778-779, 790-791 (1857).
} 
In western Europe the recognition of new states was not usually connected with a guarantee of religious freedom, as is illustrated by the recognition of the united Italy, the German Empire, the independent Belgium, or Norway. The principle of religious freedom was proclaimed by Article 6 of the General Act of the Berlin Conference in certain regions of Africa in 1885 . This Act was signed by all important European states and by the United States. ${ }^{8}$

The peace settlements after the First World War introduced in the countries between the Baltic and the Eastern Mediterranean area a new system, which defined and enlarged the minority groups to be protected and endeavored to eliminate the shortcomings of the previous collective guarantees. The minorities provisions inserted into the Peace Treaties, and the special treaties concluded for the protection of national, racial, and religious minorities, offered detailed regulation and, at the same time, provided a procedure to ascertain the violations and to enforce the provisions protecting the minorities. The League of Nations became the guarantor of the enforcement of these provisions. ${ }^{9}$

There were justified complaints against this minority protection system. The system was far from being universal. It was established for, or rather imposed only on, certain countries. Besides many procedural deficiencies, the minority treaties did not provide for equality of economic opportunities and for adequate participation in administration. Thus, through economic pressure and administrative measures the minorities could be frustrated and deprived of the enjoyment of their rights in practically every field of human relationships. There was no question, of course, of recognizing the minorities as legal entities. Political and social minorities were not granted protection.

Despite many shortcomings of the system, the institutional protection, established at Paris for the first time in history, meant genuine progress. This was recently recognized even by one of the most dissatisfied countries, Hungary. The Hungarian government in a note addressed on August I9, 1945, to Great Britain, the United States, and Soviet Russia proposed to provide for the protection of minorities "by means of some international machinery of the United Nations." The same note

Martens, to id. 418 (2d ser. 1885).

- The minority protection system was introduced into Albania, Austria, Bulgaria, Czechoslovakia, Estonia, Greece, Hungary, Iraq, Latvia, Lithuania, Poland, Rumania, Turkey, and Yugoslavia. The different international instruments for the establishment of the minorities protection system were: the so-called Minorities Treaties; the special dispositions inserted in the Peace Treaties and in other treaties; and Declarations by particular states made before the Council of the League of Nations. See Lenoun of Nations, Protection of Linguisttc, Raciaz on Religious Minorities by the League of Nations, Provisions Contained in the Various International Instruments (Geneva, 1927), (C. 8, M. 5, 1931. 1.); League of Nattons, Resolutions and Extracts from the Minutes of the Council, Resolutions and Reports Adopted ay the Assembly Relating to the Procedure to be Followed in Questions Concerning the Protection of Minorities (Geneva, $2 d$ ed. i931); J. Stone, International Guarantees of Minority Rights (London, I932); ANdre N. Mandelstam, La Protection Internationale des Minorites (Paris, I931); Jacob Robinson and Others, Were the Minoritues Treaties a Fatlune? (1943); Kunz, The Future of the International Law for the Protection of National Minorities, 39 AM. J. INT'L L. 89-95 (1945). For further bibliography see I L. F. L. Oppenhem, International Law 650 (7th ed., Lauterpacht, 1948). 
added: "The protection afforded to minorities by the League of Nations undoubtedly justified certain adverse criticism, but at least there was some protection. In many cases the very fact that such machinery existed was sufficient to restrain governments planning oppressive measures against minorities. It will be an act of retrogression if even such protection is not granted in the future to national minorities."10

\section{II}

The five Peace Treaties signed with Bulgaria, Hungary, Finland, Italy, and Rumania in Paris on February Io, $1947,{ }^{11}$ signify a new departure. The minorities protection system was abandoned and a general clause concerning the protection of human rights and fundamental freedoms was inserted into the Peace Treaties. ${ }^{12}$ For example, the Peace Treaty with Bulgaria states:

Bulgaria shall take all measures necessary to secure to all persons under Bulgarian jurisdiction, without distinction as to race, sex, language, or religion, the enjoyment of human rights and of the fundamental freedoms, including freedom of expression, of press and publication, of religious worship, of political opinion and of public meeting. ${ }^{13}$

The peace treaty with Italy includes a guarantee, concerning the exercise of the fundamental human rights as defined in the above general clause, to all persons living in former Italian territories which have been transferred to other states. ${ }^{14}$ In other words, two victorious states, Yugoslavia and France, are obligated to assure these fundamental human rights to all persons within the former Italian territories transferred to them. A third victorious state, Czechoslovakia, guaranteed full human and civic rights to the population of three villages ceded by Hungary. ${ }^{15}$

The Permanent Statute of the Free Territory of Trieste also embodied the general clause, with the addition that citizens of the Free Territory should be assured

\footnotetext{
${ }^{10}$ I Hungary and the Conference or Paris 13 (Hungarian Ministry for Foreign Affairs, Budapest, 1947). The minorities protection system is discussed in this issue by Mary G. Jones, supra.

${ }_{11}$ It was provided that the Peace Treaties shall come into force upon the deposit of ratifications by the major victorious Powers. This occurred on September 15, 1947.

${ }^{12}$ Ernest Bevin, the British Foreign Secretary, probably expressed in this respect the general way of thinking of the Western statesmen when, in June 1946 , he gave the following explanations to the Hungarian Prime Minister: "You ask that the Czechoslovak-Hungarian peace treaty should, in a separate section, insure the rights of the Hungarian minority, a method tried unsuccessfully after the First World War. Nationality complaints arose after that, too. It would be much better to insert into every peace treaty all the basic human rights which should be guaranteed to all men regardless of nationality. The United Nations would exercise jurisdiction over such measures in the peace treaties and could rush to aid those nationalities whose rights suffered injury. Far better that the countries of the United Nations exercise control over these rights than that a single nation be left to keep to the letter of the treaty." Ferenc Nagy, The Struggie Behind the Iron Curtain, 236 (I948).

${ }^{18}$ Art. 2, B. T. The same provisions are embodied in Art. 6, F. T.; Art. 2 I, H. T.; Art. 15, I. T.; Art. $3 \S \mathrm{I}, \mathrm{R}$. T.

14 $I$. T. Art. 19 \$4. The provision providing for human rights and fundamental freedoms of persons in Italian territories ceded to other states was originally a United States-Australian proposal which was attacked by the Byelorussian delegation at the Paris Conference. Selected Docunants 598.

${ }^{15} \mathrm{H}$. T. Art. $\mathrm{r}, \S_{4 \mathrm{C}}$. This provision is all the more conspicuous since, in I945-1946, Czechoslovakia deprived her Hungarian minority of nearly all human and civic rights. 2 Hungary aNd THE Conference of PARIS 150-152, and 4 id. 176-186 (Hungarian Ministry for Foreign Affairs, Budapest, 1947). Cf. Kertesz, Minority Population Exchanges: Czechoslovakia and Hutngary, 2 American Perspective r38144 (1948).
} 
of equality of eligibility for public office and that no citizen of the Free Territory should be deprived of his civil or political rights except as judicial punishment for the infraction of the penal laws of the Free Territory. ${ }^{16}$

Besides the general clause, the defeated countries were obliged to accept certain specific undertakings concerning human rights. ${ }^{17}$ For example, all five treaties forbade the existence and activities of organizations of a Fascist type which have as their aim denial to the people of their democratic rights. ${ }^{18}$ The defeated countries were obliged under the armistice agreement to set free, irrespective of citizenship and nationality, all persons held in confinement on account of their activities in favor of, or because of their sympathies with, the United Nations, or because of their racial origin, and to repeal discriminatory legislation and restrictions imposed thereunder. The Peace Treaties with Bulgaria, Finland, Hungary, and Rumania prescribe that no measures must be taken or laws enacted that will be incompatible with the purposes set forth in this provision. ${ }^{19}$ The peace treaty with Italy only forbids the prosecution or molestation of Italian nationals, including members of the armed forces, on the ground that during the war they expressed sympathy with, or took action in support of, the cause of the allies. ${ }^{20}$

The Rumanian and Hungarian Peace Treaties contain special provisions that the laws of these countries will not, either in their content or in their application, discriminate or entail any discrimination on the ground of race, sex, language, or religion of the nationals, whether in reference to their persons, property, business, professional or financial interests, status, political or civil rights, or any other matter. ${ }^{21}$

\section{III}

In the course of the Second World War the aggressive dictatorships dominated their own people and the occupied countries by ruthless oppression and negation of human rights. This fact forced and hastened actions in the camp of the United Nations for an effective international protection of human rights and fundamental freedoms for all without discrimination as to race, sex, language, or religion. This idea was expressed in the various western and allied declarations about war and peace aims, like the "Four Freedoms" Message of President Roosevelt to Congress on January 6, I94I, the Atlantic Charter of August I4, I94I, the Declaration of the United Nations of January I, 1942, the Yalta decision of the three major allies of February II, I945; and eventually was inserted into the Charter of the United Nations, which refers to human rights no less than seven times.

\footnotetext{
${ }^{10}$ Arts. 4 and 5, Permanent Statute of the Free Territory of Trieste, Annex VI to the Treaty of Pcace with Italy.

${ }^{27}$ For the full text of the pertinent provisions of the five Peace Treaties, see UNITED Narrons Yyar Book of Human Rights for r947 390-397 (r949). Cf. Andrew Martin, Human Rights in the Paris Peace Treaties, Brir. Y. B. INr'L L. 392-398 (r947).

${ }^{18}$ Art. 4, B. T.; Art. 8, F. T.; Art. 4, H. T.; Art. 17, I. T.; Art. 5, R. T.

${ }^{10}$ Art. 3, B. T.; Art. 7, F. T.; Art. 3, H. T.; Art. 4, R. T.

${ }^{20}$ Art. I6, I. T.

${ }^{21}$ Art. 3, \$2, R. T.; Art. 2, \$2, H. T.
} 
The provisions concerning the protection of human rights in the Peace Treaties concluded after the Second World War are due to American initiative and are based on American drafts. Answering a question in the course of the hearings before the Senate Committee on Foreign Relations, Secretary of State Byrnes pointed out that the ideal of fundamental human liberties and rights was at every stage of the negotiations before the American delegation. "Everything that we could possibly do to assure those rights and freedoms, we did," he stated. ${ }^{22}$

The insertion of the human rights provisions into the Peace Treaties was proposed by the American delegation at the first meeting of the Council of Foreign Ministers held in London from September II to October 2, $1945 .{ }^{23}$ This proposition was preceded by a long discussion within the American Delegation. Irrespective of other political considerations, the American experts thought it would be futile to maintain the minority protection system without recognizing the legal personality of the minorities. Since such a solution was not practicable, the general protection of human rights seemed to be a convenient alternative.

In the London and Paris sessions of the Council of Foreign Ministers the main opposition between Russia and the Western Powers was centered around important political problems, like the questions of Trieste, the Danube, and some économic provisions of the treaties. The provisions concerning the protection of human rights were more or less considered harmless declarations of principle and did not arouse much antagonism among the Great Powers. Although no draft article was agreed on at London, the Soviet delegation accepted in principle that there should be in the Treaties an article along the lines of the American proposal. The detailed negotiations took place at the meetings of the Deputy Foreign Ministers in the winter and spring of 1946. There was no great difficulty in reaching agreement on the text of the human rights article as it now appears in the Peace Treaties. There was, on the other hand, considerable argument over the clause dealing with dissolution of organizations of a Fascist type. The Western delegations did not like this article and tried to change its wording so that it would not appear to give justification for violations of the human rights article. They proposed texts describing the organizations referred to as those which had as their aim the denial of the rights guaranteed by the human rights article. The final compromise formula which was accepted for the anti-fascist clause was hardly satisfactory from the point of view of the Western Powers.

It is not without interest to note that the UN Economic and Social Council recommended in the summer of 1946 that the Peace Treaties include provisions guaranteeing human rights in the former enemy countries. Although this initiative

\footnotetext{
${ }^{23}$ Hearings, 29.

${ }^{23}$ It was decided at the Potsdam Conference of July-August 1945, that the text of the peace treaties would be prepared by the Council of Foreign Ministers of the five victorious Great Powers. See for details, James F. Byrnes, Speaking Frankly 69-72 (x947); Mosely, Peace Making, 1946, I Int'L Org. 22-32 (1946); John C. Camprberi, The United States in Worrd Affairs, 1945-x947 6I-64 (1947).
} 
was not responsible for the inclusion of human rights clauses in the five Peace Treaties, since in point of time it came after such clauses were proposed in the Council of Foreign Ministers, nevertheless it indicates a general feeling among UN members that such clauses should be included in the peace settlement.

At the Paris conference of twenty-one nations, in session from July 29 to October I5, I946, the Italian, Bulgarian, Finnish, Hungarian, and Rumanian delegations were asked to submit to the conference their observations concerning the text of the Peace Treaties drafted by the Council of Foreign Ministers. ${ }^{24}$ In comparison with the rather passive attitude of the Great Powers, with respect to the human rights clauses, the observations of some of the defeated countries are of particular interest in this field. ${ }^{23}$

The Bulgarian delegation simply referred to the fact that their own legislation had already applied, was applying, and would continue to apply the principles underlying the political clauses of the draft treaty. ${ }^{28}$ The statement of the Finnish delegation was in a similar vein. ${ }^{27}$

The Hungarians welcomed the human rights provisions with some qualifications. They pointed out that the rights and freedoms enumerated in Article 2 of the draft treaty did not contain all the "Rights of Men" and proposed that this enumeration should be completed by an exact description of these rights, such as "the right to elect domicile, freedom to choose school language, freedom to work and to engage in a calling" and that the words "without distinction of race, sex, language or religion" should be completed by the insertion of the term "of nationality." Moreover, the Hungarian delegation pointed out that the mere reference to general human rights did not seem sufficient when defining the status of the minorities. They referred to an Aide-Mémoire presented on June Ir, r946, to the Council of Foreign Ministers by the Hungarian Government, and requested that corresponding provisions should be included in the peace treaty with Rumania. ${ }^{28}$ The Hungarian delegation later submitted to the Conference a detailed project, a sort of international code, concerning the protection of minorities. ${ }^{29}$

The Italian and Rumanian delegations opposed the insertion of the human rights clause into the Peace Treaties. The Italians were of the opinion that the provisions in the draft treaty concerning the safeguarding of human rights and fundamental freedoms ought to be suppressed on the following grounds:

\footnotetext{
34 At a meeting of the Foreign Ministers of the United States, the United Kingdom, and the Sovict Union in Moscow, December 16-26, 1945, it was agreed that the draft treaties prepared by the Council of Foreign Ministers would be examined by a general conference of the allied states and that, at the same time, the five ex-enemy states would be given an opportunity to state their views concerning the treaties.

${ }^{25}$ The most important materials of the Peace Conference were published by the Department of State under the title "Paris Peace Conference, x946, Selected Documents."

${ }^{20}$ Selected Documents 888.

${ }^{27} I d$. at 1259 .

${ }^{28}$ Id. at 1065-1066. The Aide-Mémoire was published by the Hungarian government. I Hunonny AND THE Conference of Parus 135-I4I (Budapest, I947).

${ }^{29}$ I Hungary AND tHe CONFERENCE OF PARIS I42-I 47 (Budapest, I947).
} 
(I) These were superfluous, since these fundamental freedoms and rights had always inspired the legislation of democratic Italy and these principles would be solemnly confirmed by the new constitution.

(2) The fact that these would form a treaty obligation on Italy's part might lead any of the signatory Powers to have recourse to this article in order to intervene in internal Italian affairs.

(3) It was to be expected that a general agreement on this matter would be reached under the auspices of the United Nations. Therefore, it would seem advisable to avoid a clause pre-establishing a juridicial situation whereby Italy-once a member of the United Nations-would find herself in this matter in a position different from that of other members. Such a situation would be inconsistent with the declared principle of equality among all members of the United Nations.

For all these reasons, according to the view of the Italian delegation, the insertion in the treaty of a special clause concerning human rights would not be justified unless its validity were terminated at the time when Italy joined the United Nations. ${ }^{30}$

The Rumanian delegation recognized the great value of the human rights principles proclaimed in Article 3 of the draft treaty, but questioned whether their inclusion in the peace treaty would not give rise to discrimination. The Rumanian statement explained by arguments similar to those of the Italians that it would be difficult to reconcile the retention of the special provisions of Article 3 of the treaty with "the principle of sovereign equality of all Members" of the United Nations (Article II of the Charter) on the day when Rumania became a member of the United Nations. Discrepancies in this respect between the system provided for in the Charter and that provided for in the treaty would establish a serious discrimination. In view of these circumstances the Rumanian government suggested that in Article 3 it should be simply stated that Rumania, in the exercise of her full sovereign rights, undertook to ensure the effective enforcement of those human rights which were contained in the Rumanian constitution. ${ }^{31}$

Notwithstanding the national sensibility of the Rumanians, the delegation of the United Kingdom, after the adoption of Article 3 of the draft treaty by the Political and Territorial Commission for Rumania, proposed the inclusion of Article $3 \mathrm{~A}$ to read as follows:

Roumania further undertakes that the laws in force in Roumania shall not, either in their content or in their application discriminate or entail any discrimination between persons of Roumanian nationality on the ground of their race, sex, language, or religion, whether in reference to their persons, property, business, professional or financial interests, status, political or civic rights or any other matters. ${ }^{32}$

${ }^{\text {so }}$ SeLECTED DOCUMENTS 200-202.

${ }^{81}$ Id. at 706.

${ }^{32}$ Id. at 734 . 
The object of the British proposal was "to relieve the suffering of the Jews in Eastern Europe, by specifying the obligation of the Rumanian Government to respect the principle of non-discrimination between Rumanian nationals."

Since this proposal did not obtain the necessary two-thirds majority vote in the Political and Territorial Commission for Rumania, ${ }^{33}$ it remained for the Plenary Conference to decide the matter by a special vote. Eventually Article $3 \mathrm{~A}$ was adopted by a vote of $\mathrm{I}_{4}$ to 7 by the Plenary Conference, ${ }^{34}$ and inserted both into the Rumanian and Hungarian peace treaties. ${ }^{35}$

\section{IV}

The Peace Treaties do not contain an exhaustive enumeration of human rights and fundamental freedoms. The general clause mentions, by way of example, the freedom of expression, of press and publication, of religious worship, of political opinion, and of public meeting. There were no discussions in the Council of Foreign Ministers and in the Conference of Paris about the meaning of these human rights and freedoms because there were no attempts to define their contents. The other human rights provisions are related to the previous internal policy and political regimes of the ex-enemy countries and are very far from being a part of a comprehensive system.

Secretary Byrnes in his report to the Senate, gave the following general explanations about the nature of the human rights provisions:

Other benefits granted to the people of the ex-enemy states assure the maintenance of their basic human rights and fundamental freedoms. These clauses constitute an international obligation and assure other states the right to see to it that they are maintained. In the preparation of these guarantees we also took precautions to prevent the reemergence of identifiable prewar and wartime anti-democratic elements and the reemergence of prewar Fascism. No limitations upon the democratic freedom and development of the people are contained in the treaties. ${ }^{36}$

It is not by accident that the insertion of a list of human rights and a definition of their meaning was avoided during the peace-preparatory work. The reason for this policy was revealed on several occasions at the Paris Conference. The United States delegation objected to a Yugoslav proposal to be inserted into the Italian Treaty because the new article:

attempts to define in detail certain of the human rights and fundamental frcedoms which are covered by the broad language of draft article I4. Such particularization of the human rights and the fundamental principles is undesirable since they cannot all be enumerated in the draft treaty and omissions may lead to confusion with respect to the

\footnotetext{
${ }^{23}$ The Commission approved Article $3 \mathrm{~A}$ by a majority of seven votes to five. Id. at 736 . Mr. Bevin pointed out in the plenary session that: "It would be difficult for Great Britain to accept the treaty unless equal treatment were accorded to all nationals in Rumania." Id. at 818.

st Id. at 822 .

${ }^{35}$ The same British proposal was made in the Political and Territorial Commission for Hungary. Id at III3.

${ }^{30}$ Hearings, 6.
} 
intent of the drafters. Consequently it is better not to try to improve on the broad language already contained in draft article $14 .^{37}$

The motives for this attitude are further explained in a Note of the Legal and Drafting Commission of the Conference, which opposed an amendment of the Australian delegation. The Australians proposed the insertion into the Peace Treaty with Finland of a new section providing for the setting up of a European Court of Human Rights. In the view of the Commission:

The practical application of Human Rights is a world-wide duty which, in accordance with the United Nations Charter, has been entrusted to the Economic and Social Council, which has set up a Commission on Human Rights. These two bodies are fully competent, both to establish the principles and to decide on the measures to be applied in order to ensure the guarantee of such rights.

As long as no fundamental understanding has been arrived at on the principles involved, it is impossible in the present state of international law to compel a State to accept the decisions of an international legal body in this matter. ${ }^{38}$

This text clearly implies that the draftsmen of the treaty had in their mind a uniform standard of human rights to be defined by the competent bodies of the United Nations and did not want to create by the Peace Treaties a special system of human rights. According to their idea, the competent organs of the United Nations would fill up the human rights framework of the Peace Treaties with the necessary material contents. As to the difficulties which may arise meanwhile in the interpretation or application of the human rights provisions, the same Note of the Legal and Drafting Commission refers to the provisions of the Peace Treaties establishing a machinery for the settlement of the disputes concerning the interpretation and execution of the treaties.

A similar interpretation was given as to the implementation of the human rights provisions of the Peace Treaties by one of the chief American promoters of these

${ }^{37}$ SELECted Documents 422 . Article 15 of the $I$. $T$. was Article 14 in the draft treaty.

${ }^{38}$ Selected Documents, 1280 , 128I. The same Note of the Legal and Drafting Commission has a somewhat different wording on p. 1329. The Australian proposal, put forward for the Italian and other Peace Treaties as well, intended "that a new Part should be included in the Treaty providing for the establishment of a European Court of Human Rights with jurisdiction to hear and determine all disputes concerning the rights of citizenship and enjoyment of human rights and fundamental freedoms provided for in the treaty. The Australian case for this proposal rested on the belief that the general declarations contained in the treaty in support of human rights and fundamental freedoms were not sufficient, standing alone, to guarantee the inalienable rights of the individual and that behind them it was essential that some sufficient sanction and means of enforcement should be established. It was proposed that the Court of Human Rights should have the status parallel to that of the International Court of Justice and that the Court would have the additional obligation of making reports to the Economic and Social Council of the United Nations on its working in relation to the rights within its jurisdiction. It was contemplated that the jurisdiction of the proposed tribunal should be voluntarily accepted by States as an essential means of international supervision of the rights of individuals and as a necessary method of giving force and effect to obligations accepted in general terms." SELECTED DOCUMENTS 444-445.

It is not without interest to note that the legal committee of the European Consultative Assembly voted 13 to 7 on September I, 1949, to create an international court of human rights to guarantec basic freedoms in Europe. The proposed court would hear cases referred to it by an inquiry commission. The two bodies would enforce a proposed guarantee that a twelve-point "Bill of Rights" will be respected in the member states of the Council of Europe. N. Y. Times, Sept. 2, r949. P. 3, col. 3. 
clauses, Secretary Byrnes. He emphasized before the Senate Foreign Relations Committee that "it has the same assurance that every other provision in these treaties has." ${ }^{39} \mathrm{He}$ recalled that the American government always placed great importance on human rights and as far back as Yalta undertook to have the Three Powers agree as to these freedoms. The Peace Treaties, however, are of a different nature. "The ex-enemy state itself has solemnly obligated itself in this agreement to assure the fundamental freedoms. It is endorsed by the United Nations signing these treaties. It is the strongest assurance that I can think of."

It is beyond doubt that according to the general rules of international law, the ex-enemy states have assumed special treaty obligations to secure human rights and fundamental freedoms to all persons under their jurisdiction. As to the assurances of the execution of these treaty obligations, the pertinent texts are to be found in the final clauses of the peace treaties. These provisions provide two kinds of procedures.

For a period not to exceed eighteen months after the coming into force of these treaties, ${ }^{41}$ the Heads of the Diplomatic Missions of the chief allied powers in Rome, Sofia, Budapest, Bucharest, and Helsinki, ${ }^{42}$ acting in concert, represent the United Nations in dealing with the ex-enemy governments in all matters concerning the execution and interpretation of the respective treaties. The Heads of the Diplomatic Missions of the allied powers were designated to give such guidance, technical advice, and clarification as might be necessary to insure the rapid and efficient execution of the respective Peace Treaty and the governments of the defeated countries were obliged to afford them all necessary information and assistance that they might require in the fulfillment of their task. ${ }^{43}$

The second method of settling disputes is of a more general nature and is not restricted by the time limit of eighteen months. Any dispute concerning the interpretation or execution of the treaties, which is not settled by direct diplomatic negotiations, shall be referred to the Heads of Missions of the chief allied nations. ${ }^{44}$ If they do not resolve the dispute within a period of two months, it shall be referred at the request of either party to the dispute to a Commission composed of one representative of each party and a third member selected by mutual agreement of the two parties from nationals of a third country. "Should the two parties fail to agree within a period of one month upon the appointment of the third member, the

${ }^{40} \mathrm{Ibid}$.

${ }^{30}$ Hearings, 14.

11 March 15, 1949, marked the conclusion of that period.

12 In Rome the Ambassadors of France, the Soviet Union, the United Kingdom, and the United States; in Sofia, Budapest, and Bucharest the Heads of the Diplomatic Missions of the Soviet Union, the United Kingdom, and the United States; in Helsinki the Heads of the Diplomatic Missions of the Soviet Union and the United Kingdom.

${ }^{48}$ Art. 35, B. T.; Art. 34, F. T.; Art. 39, H. T.; Art. 86, I. T.; Art. 37, R. T.

"They are the same diplomatic representatives as in the previous case. See note 42, supra. Cf. M. Domke, Settlement of Disputes Provisions in Axis Satellite Peace Treatics, $4 \mathrm{1}$ AM. J. INT'1 L. 911-920 (1947). 
Secretary-General of the United Nations may be requested by either party to make the appointment." $"$ s5

It is not without interest to note that in the Paris Conference the British, American, and French delegations proposed that any dispute concerning the execution or the interpretation of the Peace Treaty, which could not be settled by direct diplomatic negotiations, at the request of any party to the dispute, might be referred to the International Court of Justice. This proposition, strongly opposed by the Soviet delegation, ${ }^{46}$ was accepted at the Conference by a vote of 15 to $6 .^{47}$ The Council of Foreign Ministers, however, under Soviet pressure, changed this rule in the sense indicated above and thus all reference to the International Court of Justice was eliminated from the Peace Treaties.

\section{V}

The optimistic expectations as to the interpretations and executions of the human rights provisions of the Peace Treaties have not been so far justified by practical experience. There were no complaints about violations of these provisions in Italy and Finland. In both countries individuals effectively enjoy a fair degree of civic liberties and freedoms in the western sense.

The situation is entirely different in Bulgaria, Hungary, and Rumania. These countries were liberated and occupied by Russian troops and have been living ever since under strict Russian control. The ideological clashes between East and West in the Danubian area are mainly centered around the meaning of the human rights clauses of the Peace Treaties. Some of the constitutional provisions of the satellite countries appear to give formal satisfaction in this respect. ${ }^{48}$ In practice, however, these countries have gradually been transformed to police states ruled by a communist minority.

It has been one of the consequences of this evolution that in Eastern Europe the solemn pledges of Yalta are not kept. Various forms of Soviet interferences have hindered the formation of democratic institutions and representative governments through free elections. "A freely elected government in any of these countries would be anti-Soviet, and that we cannot allow," declared Marshal Stalin at Potsdam, ${ }^{49}$ according to a member of the American delegation. The ruthless suppression of democratic freedoms made impossible the substantial implementation of the human rights clauses of the Peace Treaties. ${ }^{\text {so }}$

${ }^{45}$ Art. 36, B. T.; Art. 35, F. T.; Art. 40, H. T.; Art. 87, I. T.; Art. 38 R. T. According to the second paragraph of the same articles: "The decision of the majority of the members of the Commission shall be the decision of the Commission, and shall be accepted by the parties as definitive and binding."

${ }^{10}$ Selected Documents $443-444$.

17 Id. at 608 .

${ }^{18}$ Some of the relevant texts were published in the United Nations Yearbook on Human Rights, 1946 (1947), and in the Yearbook ON Human Rights, 1947 (1949).

"Philip E. Mosely, Face to Face With Russia, Foreign Policy Association, Headline Series, No. 7o, 1948, p. 23 .

so A Brief submitted in March, 1947, by the Rumanian-American National Committee to the Senate Foreign Relations Committee characterized the Rumanian situation in the following way: 
In the heyday of Nazism, Goering allegedly said: "I determine who is a Jew." Similarly, the "Fascist, reactionary, and imperialist" denominations have no objective criteria in the communist vocabulary but have been freely used to silence persons opposing communist domination. In this spirit, the anti-fascist provisions of the Peace Treaties were one of the means for the elimination from the public life of persons who were reluctant to follow blindly the increasingly oppressive pattern of the communist puppet governments.

Shortly after the coming into force of the Peace Treaties, the Bulgarian, Hungarian, and Rumanian applications for membership in the United Nations were opposed by the United Kingdom and the United States mainly on the ground that these countries had systematically violated the human rights clauses of the Peace Treaties, and had thus refused to carry out the international obligations contained in the Charter. ${ }^{51}$ Italy and Finland were not similarly accused but their admittance was vetoed by the Soviet Union. According to the Soviet and Polish point of views explained in the Security Council, all ex-enemy states are in the same position and must be admitted collectively at the the same time to the United Nations. At this occasion, the open clash in the Security Council made it clear that the meaning of the human rights provisions is entirely different according to Western and Eastern interpretation. The Eastern view was expressed by the Polish delegate: "the question of the manner in which a country fights for its internal security is entirely an internal problem of that country." ${ }^{2} 2$

"The principles contained in article 3 with regard to human rights and fundamental freedoms cannot but be endorsed by eyerybody. There are, however, no guaranties that these principles will be implemented. Rumania will therefore continue to have a quisling government imposed by the Sovict Union. As it is well known, this government, under the protection of Soviet troops, organized the most shameful mockery of elections last November. The United States Government has officially protested that these elections were not free; that they were marked by manipulation and terrorism, and that the franchise was effectively denied to important sections of the population." Hearings, 167.

In Rumania the Radescu coalition government was removed from office on February 28, 1945 , following a Russian ultimatum, and was succeeded by the communist-dominated Groza government. Free elections never took place and the leaders of the democratic parties were put into jail or driven into exile. See J. F. Byrnes, Speaking Frankiy, 50-53; N. Radescu, Forced Lazor in Rumania (1949); R. H. MARkam, Rumanis UNDER the Soviet Yoke (1949). The development was similar in Bulgaria where Nicola Petkov, leader of the Agrarian Party, was executed. Hungary's position was unique in the sense that it is the only satellite country where "free and unfettered" elections took place, in November, 1945. At these elections the Smallholders Party received nearly 60 per cent of the votes and the Communists only 17 per cent. Despite the clear-cut non-Communist parliamentary majority, the Moscow educated Communist leaders dominated the Hungarian public life with the help of the occupying Sovict forces. The non-Communist Parties were gradually liquidated and their leaders forced into exile. Sce Schonfeld, Soviet Imperialism in Hungary, 26 Foreign AfFars 554-565 (1948); Ferenc NaGr, op. cit supra note 12.

Sovict violations of the respective treaty obligations are summed up in a document submitted to the Senate Committee on Foreign Relations, I8 BuLL. 740-742 (1948). The whole evolution is described in more detail by I. A. Stone, American Stupport of Free Elections in Eastern Europe, 27 Bull. 311-323, 407-413 (1947). Cf. A. Gyorgy, Governments of Danubian Europe (1949).

${ }^{62}$ United Nations Security Council, Official Records, Second Year, Nos. 90, 91, 92, Septcmber 25 and 29, and October 1, 1947. The question of admission of the Soviet satellites was brought again to the Security Council in 1948 and 1949 .

${ }^{52}$ Id. No. $9 \mathrm{r}$, at 2447 . 
In the eighteen months' period, after the coming into force of the treaties, the United Kingdom and the United States governments have repeatedly made protests for flagrant treaty violations and requested information. The governments of Bulgaria, Hungary, and Rumania have refused to consider these representations and requests on the ground that in such cases the designated three Chiefs of Missions should act in concert. The Soviet Chiefs of Mission, however, were not disposed to cooperate with a view to action in concert. By this attitude the implementation of the Peace Treaties has been obstructed. A statement released by the United States government on March 16, 1949, held Bulgaria, Hungary, and Rumania responsible for violation or non-performance of their treaty obligations and alleged that the Soviet Union had brought about this situation. ${ }^{\text {53 }}$

The last Western move in connection with the human rights clauses is still in progress. The United States representatives in Bulgaria, Hungary, and Rumania, in notes delivered on April 2, 1949, charged the three governments with having violated their obligations under the respective Peace Treaty articles requiring them to secure to all persons under their jurisdiction the enjoyment of human rights and the fundamental freedoms. ${ }^{54}$

The notes pointed out that the Bulgarian, Hungarian, and Rumanian governments had deliberately and systematically denied to their people, through measures of deprivation and oppression, the exercise of the very rights and freedoms which they had pledged to secure to them under the Peace Treaty. The note addressed to the Bulgarian government charged:

Through the exercise of police power the Bulgarian Government has deprived large numbers of its citizens of their basic human rights, assured to them under the treaty of peace. These deprivations have been manifested by arbitrary arrests, systematic perversion of the judicial process, and the prolonged detention in prisons and camps, without public trial, of persons whose views are opposed to those of the regime.

Similarly, the Bulgarian Government has denied to persons living under its jurisdiction, as individuals and as organized groups, including democratic political parties, the fundamental freedoms of political opinion and of public meeting. It has dissolved the National Agrarian Union, the Bulgarian Socialist Party and other groups, and has imprisoned many of their leaders. With the Treaty of Peace barely in effect and in the face of world opinion, the Bulgarian Government ordered the execution of Nikola Petkov, National Agrarian Union leader, who dared to express democratic political opinions which did not correspond to those of the Bulgarian Government. Proceedings were instituted against those deputies who did not agree with its policies, with the result that no vestige of parliamentary opposition now remains, an illustration of the effective denial of freedom of political opinion in Bulgaria.

By restrictions on the press and on other publications, the Bulgarian Government has denied to persons under its jurisdiction the freedom of expression guaranteed to them dation on the part of its officials, the Bulgarian Government has made it impossible for

${ }^{53} 20$ BuLl. 39 (1949).

The notes were published in 20 BuLr. $450-453$ (1949) and N. Y. Times, Apr. 3, 1949, §I, p. I, col. 3 and p. 4, col. I. The Canadian Government associated itself with the contents of the respective United States notes. 
under the treaty of peace. By laws, administrative acts, and the use of force and intimiindividual citizens openly to express views not in conformity to those officially prescribed. Freedom of the press does not exist in Bulgaria.

By legislation, by the acts of its officials, and by "trials" of religious leaders, the Bulgarian Government has acted in contravention of the express provision of the Treaty of Peace in respect of freedom of worship. Recent measures directed against the Protestant denominations in Bulgaria, for example, are clearly incompatible with the Bulgarian Government's obligation to secure freedom of religious worship to all persons under its jurisdiction.

The political situation being similar in the three Danubian satellite countries, the notes addressed to the Hungarian and Rumanian governments have, mutatis mutandis, a similar content and tone. The note addressed to the Hungarian government points out particularly that by arbitrary proceedings against religious leaders, as in the cases of Cardinal Mindszenty and Lutheran Bishop Ordass, the Hungarian government has attempted to force the submission of independent church leaders and to bring about their replacement with collaborators subservient to the Communist Party. The note addressed to the Rumanian government alludes to the extensive control assumed by state authorities over the practice of religion, including the application of political tests. These powers have been used to destroy by government decree a major religious body, i.e., the Greek Catholic Uniate Church, and to transfer its property to the state.

The satellite countries denounced the American note as an illegitimate interference in their domestic affairs and stated in their replies ${ }^{55}$ that they had fully complied with the human rights provisions of the Peace Treaties.

The Bulgarian reply emphasized that:

After Bulgaria had been granted the most democratic Constitution in the world, and the people had been guaranteed legal power to exercise and defend its rights and freedoms, the Bulgarian Government, as government of a sovereign state, cannot agree to permit other states the appreciation of its acts, for which it is solely responsible to the National Assembly. This Government can even less agree to suffer the criticism of foreign powers, in so far as the activities of Bulgarian courts are concerned, being (in existence) by virtue of the Constitution and functioning in public in accordance with the most modern and most democratic of laws.

The Bulgarian Government will repel every attempt of interference in the domestic affairs of Bulgaria and will consider as an unfriendly act any attempt to force it to accept treatment as a state whose internal acts would be subject to judgment by foreign powers.

The Hungarian reply pointed out that it is the United States that launches reproaches against Hungary, "whereas it is notorious that in the United States serious discrimination exists between citizens of different race and color and that, by far, not every person can equally enjoy human rights." The Hungarian note, charging the United States with misinterpretations and repeated violations of the Peace Treaty, characterized the note of the United States as

${ }^{85}$ The full text of the replies was published in 20 BuzL. $755-759$ (1949). 
an attempt at illegitimate interference in the domestic affairs of this country and a new phase in the campaign of reactionary incitement pursued by the imperialist quarters of the United States in the service of their aims threatening peace and directed against the Hungarian people's democracy.

The Rumanian reply, using a colorful diplomatic language, concluded that the note of the United States government:

endeavors to lead astray world public opinion which condemns its policy of racial discrimination, its barbarous acts of lynching, its drowning out of democratic political opinion, its trials of men of culture and representatives of the working people who fight for democracy and peace, its incitement to war and policy of aggressive pacts, its nurturing of breeding grounds of war, and its support of fascist bands which kill women and children en masse, all of which are in reality a brutal violation of the fundamental rights and liberties of men.

The United States government considered the satellite notes as unsatisfactory replies to specific charges, ${ }^{56}$ and invoked the relevant Peace Treaty articles providing procedure for the settlement of such disputes. ${ }^{67}$ At the same time, on May 3I, I949, the American Chiefs of Mission in the three capitals requested their British and Soviet colleagues to meet with them to consider the disputes in accordance with the procedure specified in the Peace Treaties. ${ }^{58}$

The Soviet government, in a note delivered in Washington on June II, I949, refused cooperation by the Soviet Ambassadors with the American and British Ministers in Bulgaria, Hungary, and Rumania in an effort to settle the disputes which had arisen about the fulfillment of the human rights obligations under the Peace Treaties. ${ }^{69}$ The Soviet reply contended that:

Actions of the Governments of Bulgaria, Hungary and Rumania concerning which the Government of the United States expressed its dissatisfaction in notes of April 2, this year, are not only not a violation of the peace treaties, but on the contrary are directed toward fulfilment of peace treaties, which make it obligatory on countries in question "to wage a struggle against organizations of a Fascist type and other organizations which pursue the aim of depriving the people of their democratic rights."

Of course, such measures carried out by Bulgaria, Hungary and Rumania for the purpose of carrying out the articles of the peace treaties are fully within the domestic competence of these countries as sovereign states.

The Soviet Government appraises the endeavor of the United States Government artificially to convert this question into a subject of dispute as a direct attempt to make use of the peace treaties for intervention in the internal affairs of Bulgaria, Hungary and Rumania, with the view of bringing pressure to bear on their internal policy.

Following the Soviet refusal, the British and the United States governments, in notes of August I, I949, i.e., after the elapse of the two months' period prescribed by the Peace Treaties, asked the governments of the three satellite countries to join them

Eo Id. at 759 .

${ }^{57}$ Notes wcre delivered in this sense by the American Legations in Sofia, Budapest, and Bucharest. ld. at $756,758,759$.

${ }^{88}$ Art. 36, B. T.; Art. 40, H. T.; Art. 38, R. T.

${ }^{80} 20$ BuLl. 824-825 (1949); N. Y. Times, June I4, I949, p. 20, cols. I and 2. 
in appointing the Commissions provided by the Peace Treaties for the settlement of disputes. ${ }^{60}$ Since the satellites refused to join in setting up these Commissions, the United States expressed once more in a note of September 19, 1949, its determination to secure compliance by the satellite governments with their treaty obligations. ${ }^{01}$ Secretary Acheson, in his address to the United Nations General Assembly on September 2, 1949, pointed out that the United States favored submission to the International Court of Justice of the question whether the three Danubian governments were under obligation to carry out the treaty procedure. ${ }^{.2}$

The observance in Bulgaria and Hungary of human rights and fundamental freedoms including questions of religious and civil liberties, with special reference to the trials of Cardinal Mindszenty and other church leaders, was raised by the Bolivian and Australian governments before the third session of the United Nations General Assembly. The legal and political problems involved were debated at length in the General Committee, in an Ad Hoc Political Committee, and in the General Assembly. Eventually, the General Assembly adopted on April 30, 1949, by a vote of 34 to 6 , a resolution expressing deep concern at the grave accusations made against the two governments and noting with satisfaction that steps had been taken by several states signatories to the Peace Treaties with Bulgaria and Hungary regarding these accusations. The resolution expressed "the hope that measures will be diligently applied, in accordance with the Treaties, in order to ensure respect for human rights and fundamental freedoms" and drew "the attention of the Governments of Bulgaria and Hungary to their obligation under the Peace Treaties, including the obligation to cooperate in the settlement of all these questions." ${ }^{\text {B3 }}$ It was decided to retain the question on the agenda of the fourth session of the General Assembly.

Secretary of State Acheson, on September 14, 1949, disclosed to a news conference that the human rights violations of Bulgaria, Hungary, and Rumania were a matter to be considered by the United Nations Assembly, since these countries had "compounded their earlier violations by this subsequent refusal to carry out the procedures for the settlement of disputes, obligations which they specifically assumed in the peace treaties themselves." ${ }^{84}$ The Australian Government has also proposed that the fourth session of the United Nations General Assembly take up the question of human rights in Rumania at the same time that it reviews the religious trials and other similar human rights problems in Bulgaria and Hungary. ${ }^{65}$

${ }^{60} 21$ Bull. $238^{\circ}$ (1949); N. Y. Times, August 2, 1949, p. 4, col. 2. Since April 2, 1949, simultaneously with the American diplomatic action, an exchange of notes took place between the British government and the three satellite states. The texts of these notes and replies have been appended to a letter of September 19, 1949, from the United Kingdom Representative to the Secretary General of the UN. See UN Doc. A/990. The texts of the American exchange of notes with the satellite countrics have been submitted to the UN Secretary General by a communication of Sptember 19, 1949. See UN Doc. A/985.

${ }^{\circ 1}$ N. Y. Times, Sept. 20, 1949, p. 4, col. 3.

${ }^{62}$ N. Y. Times, Sept. 22, 1949, p. 6, col $\mathrm{r}$.

${ }^{\circ}$ United Nations Doc. A/85x. The text of the resolution was also published in 20 Butr. 613 (1949).

of N. Y. Times, Sept. 15, I949, p. I, col. 3, P. 7, col 6.

${ }^{05}$ N. Y. Times, August 24, 1949, p. 15, col. 6. 
The United Nations General Assembly, on October 22, 1949, gave expression of its "increased concern" at the charges that religious and political freedoms were being violated in Hungary, Rumania, and Bulgaria and asked the International Court of Justice to examine the legal possibilities of an inquiry. Forty-seven members of the Assembly voted for a resolution to seek an advisory opinion from the International Court and to keep the charges on the agenda for reopening next year. Seven countries, including Yugoslavia, abstained, and only the five Soviet bloc states voted against the resolution. ${ }^{66}$

\section{VI}

The execution of the human rights clauses of the Peace Treaties would be, under normal conditions, a relatively easy matter, as is demonstrated by the examples of Italy and Finland. The protection of human rights in the ex-enemy states became an international obligation, assumed by them when they signed and ratified the Peace Treaties. The argument that this would be a matter of purely domestic jurisdiction is clearly not valid. Obligations solemnly pledged in an international instrument and accepted without reserve, cannot be considered subsequently as a matter of merely domestic concern. This is an elementary principle of international law: the denial of it would make the conclusion of treaties purposeless. This principle was emphasized by Stalin to Harry Hopkins, during the difficult days of Russia, in July I94I: "Nations must fulfill their treaty obligations, he [Stalin] said, or international society could not exist." ${ }^{37}$ Stalin alluded in this remark to the treaty-breaking practice of Nazi Germany and stated that without a minimum moral standard nations could not co-exist. It is an unfortunate fact that since the conclusion of the war the Soviet policy has been disregarding this primary necessity for an orderly international life.

In reality, the controversy connected with the human rights is not of a legal nature. The actual difficulty lies in the fact that the three Danubian satellite states are from the point of view of practical international politics parts of Soviet Russia. All major decisions of the minority communist dictatorships reflect the attitude of Moscow. Thus, the whole problem of the execution of the Peace Treaties has been shifted onto a higher level, namely the sphere of major East-West controversies.

In the light of the above analysis, the prospects for securing fulfillment of human rights provisions in the Danubian satellite countries do not seem to be bright in the immediate future. In our bipolar world the issues in international relations are more centered around human rights and fundamental freedoms than around any other problem. The ideological differences seem to be of an overwhelming nature and importance. The deepest conflict between East and West is neither military nor economic: the issue is one of opposing ideologies, a contest for men's minds. Communist totalitarian dictatorship, like Nazi dictatorship, cannot tolerate free insti-

${ }^{00}$ N. Y. Times, Oct. 23 , I949, p. I, col. 8, p. I4, col. I.

${ }^{\circ 7}$ R. E. SHerwood, Roosevelt aNd Hopkins 328 (I948). 
tutions but demands from each individual total allegiance and establishes total control over all human relationships. It is hardly conceivable that a communist minority government, puppet of a foreign state, would be willing to apply effectively provisions protecting rights and freedoms of individuals against the omnipotence of a totalitarian state. This is the reason for the non-execution of the human rights provisions of the Peace Treaties by the Danubian satellite countries.

Despite the recent discouraging experiences, the insertion of the human rights articles into the Peace Treaties cannot be considered futile. These clauses form concrete legal obligations, which may be used systematically as a means of pressure upon the Soviet satellites for more effective execution of human rights provisions. It is probable that, for the time being, protests of the West are not likely to bring about a fundamental change in the behavior of the satellites. This anomalous situation, however, may serve the purpose of focusing world opinion upon the necessity for a more operative human rights program, such as that being worked out by the United Nations. This trend, if supported by overwhelming public opinion in the free countries, must have, in the long run, a moderating influence upon the communist-dominated countries. With radio and other means of communication, nations cannot long be kept in watertight compartments by totalitarian dictatorships. The barbed wire planted on the western boundaries of the satellite countries cannot repel the march of ideas of human freedom and civic liberties. To support and further this inevitable evolution is the deeper significance and political utility of western actions based on the human rights clauses of the Peace Treaties 